\title{
Is Routine Histopathological Examination of Appendix Mandatory?
}

\author{
Acharya $\mathbf{A}^{1 *}$, Basnet $\mathbf{R B}^{2}$, Singh $\mathbf{R R}^{3}$, Bastakoti $\mathbf{R}^{3}$, Paudel $\mathbf{S R}^{4}$ \\ 'Senior Consultant Surgeon, ${ }^{4}$ Consultant surgeon, Western Regional Hospital, Pokhara, Nepal \\ ${ }^{2}$ Asst Professor, NAMS, Bir Hospital, Kathmandu, Nepal \\ ${ }^{3}$ Consultant Surgeon, Koshi Zonal Hospital, Biratnagar, Nepal
}

\section{Keywords}

Appendix, Histopathological examination, Remote areas.

\section{Corresponding author \\ ${ }^{*}$ Dr. Arjun Acharya \\ Senior Consultant Surgeon \\ Western Regional Hospital \\ Pokhara, Nepal \\ E-mail: drarjunacharya@gmail.com}

\begin{abstract}
Introduction: No age is immune for appendicitis and appendicectomy. Appendicectomy is one of the most common operations done all over the world. Emergency surgeries are more common than elective. Histopathological examination of every excised tissue is strongly recommended but trained manpower and laboratory for histopathological examination is not available in every hospital in our country.
\end{abstract}

Methods: It is a prospective observational study of appendectomy performed at Bir Hospital, Kathmandu, Nepal country over a period of three years. Histopathological examination reports and peroperative findings were collected. Histopathological examination was performed by postgraduate pathologist at different hospitals and laboratory centres. Peroperatively appendices were categorized as non malignant looking appendix and suspicious malignant looking appendix by operating surgeons at different hospitals. Histopathological examination reports were compared with peroperative categorization.

Results: Eight hundred and fifty five appendectomies performed during the study period were analysed. Eight hundred thirteen (95.1\%) cases had non-malignant looking appendix and 42 (4.9\%) cases had malignant looking appendix peroperatively. Seven $(0.8 \%)$ cases were found malignant and $848(99.2 \%)$ cases were found non-malignant on histopathology report. All seven (16.67\%) malignant cases were from 42 suspicious malignant looking cases.

Conclusion: Routine histopathology examination is mandatory for only peroperative suspicious malignant looking appendix.

\section{INTRODUCTION}

Appendicectomy is one of the most common operations done all over the world. Emergency surgeries are more common than elective. No age is immune for appendicitis and appendicectomy. Histopathological examination of every excised tissue is strongly recommended but trained manpower and laboratory for histopathological examination is not available in every hospital in our country.
This study has been designed to ameliorate confusions on which specimens are recommended for histopathological examination especially in areas where no laboratory services are available and transportation to deliver specimens to equipped laboratory is expensive.

\section{METHODS}

It was a prospective observational study conducted at Bir 
Hospital, Kathmandu, from January 2012 to December 2014. Ethical clearance was obtained from Institutional Review Board.

Eight hundred and fifty five patients were included in the study. Their peroperative findings were categorized into normal looking appendix and suspicious malignant looking appendix. Peroperative finding were compared with histopathological reports. A performa was prepared by the principal author and was filled by the principal author and the coauthors while working at Bir Hospital. All the appendectomies performed by the authors for whom histopathological investigation was done were included in the study. All patients for whom either Histopathological examination were not done or did not report with same were excluded.

Data were analysed as percentage of the total in the respective categories as presented.

\section{RESULTS}

There were 855 cases. Maximum numbers of cases were in 20 - 40 year age group among both the sexes. Five hundred fifty four $(64.8 \%)$ were males and three hundred one (35.2\%) were females. Eight hundred thirteen (95.1\%) cases had non-malignant looking appendix and 42 (4.9\%) cases had malignant looking appendix peroperatively. Seven (0.8\%) cases were found malignant and 848 (99.2\%) cases were found non-malignant on histopathology report. All seven (16.67\%) malignant cases were from 42 suspicious malignant looking cases. The results have been summarized in Table 1.

Table 1: Comparative data of peroperative findings with histopathology examination report

\begin{tabular}{lccc}
\hline $\begin{array}{l}\text { Histopathol- } \\
\text { ogy examina- } \\
\text { tion report }\end{array}$ & $\begin{array}{c}\text { Non malignant } \\
\text { looking } \\
\text { appendix }\end{array}$ & $\begin{array}{c}\text { Suspicious } \\
\text { malignant looking } \\
\text { appendix }\end{array}$ & Total \\
\hline Non-malignant & 813 & 35 & 848 \\
Malignant & 0 & 7 & 7 \\
Total & 813 & 42 & 855 \\
\hline
\end{tabular}

Table 2: Age and sex distribution

\begin{tabular}{lccccccc}
\hline Sex & \multicolumn{5}{c}{ Age } & & Total \\
& $<20$ & $21-40$ & 41 & 61 & $>80$ & \\
& years & years & -60 & -80 & years & \\
Males & 130 & 350 & 53 & 15 & 6 & 554
\end{tabular}

\begin{tabular}{lcccccc} 
Females & 79 & 181 & 25 & 9 & 7 & 301 \\
Total & 209 & 531 & 78 & 24 & 13 & 855 \\
\hline
\end{tabular}

Fig 1: Malignant looking Appendix specimen

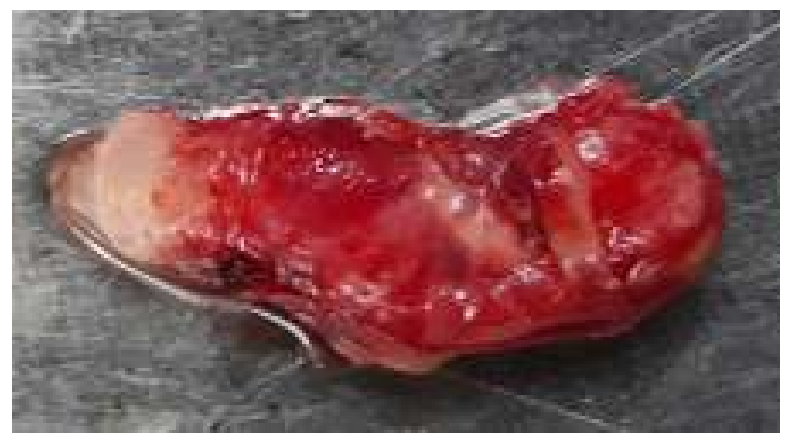

Fig 2: Normal appendix

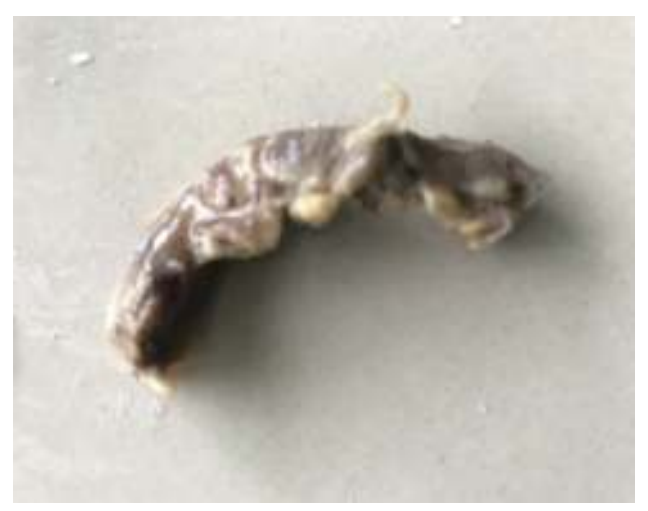

Fig 3: Histopathology of appendix

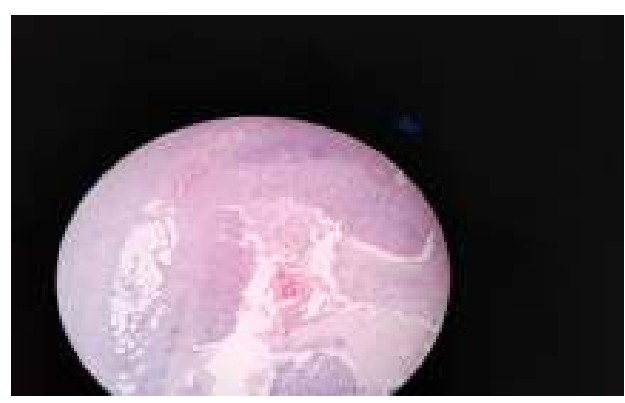

\section{DISCUSSION}

An appendectomy is the surgical removal of the vermiform appendix. This procedure is normally performed as an emergency procedure, when the patient is suffering from acute appendicitis. The first recorded successful appendectomy was on December 6, 1735 at St. George's Hospital in London, when French surgeon Claudius Amyand described the presence of a perforated appendix within the hernial sac of an 11 year old boy who had undergone successful herniotomy ${ }^{1}$. Appendicectomy can be performed by open technique or laparoscopically. Histopathological examination of the appendix is routinely 
performed because there are still a number of unusual diagnoses found in appendicectomy specimens supporting the continued use of routine histology $y^{2,3}$. In our study only $0.8 \%$ was found malignant, and $99.2 \%$ were found to be non-malignant. High number of appendicitis in adolescents and young adults were found in our study, which is similar to other studies. Routine histopathological evaluation after appendicectomy had identified unexpected findings among pediatric patients including carcinoid tumor, pinworm, granuloma, eosinophilic infiltrates, and others, but reoperation for carcinoid tumors were not needed due to complete surgery $y^{4}$. To avoid missing of any clinically important and treatable conditions, routine histopathological examination is useful although no malignant diseases were found among 480 resected appendices in a study of Jat et $a l^{5}$. Retrospective analysis of 238 histopathological report of appendicectomy specimens performed at single UK center recommend and justify the current practice of routine histopathological examination of resected appendix ${ }^{6}$.

In our study only $42(4.9 \%)$ cases were suspicious malignant looking peroperatively and out of them seven (16.67\%) cases were malignant proved histopathologically. No malignant cases were reported among non-malignant looking appendix peroperatively. Operating surgeons' bias may have occurred to categorise appendix specimen peroperatively because different surgeons were included in the study. In a study conducted at Germany, when 595 appendicectomy cases, with no suspicion of malignancy pre and peroperatively, were included; three cases were found to be carcinoid tumour at tip of the appendix with size below $2 \mathrm{~cm}$.

The study concluded that routine histopathological analysis did not help in the management and patients' outcome of any of the cases ${ }^{7}$. Similar results were given in an Iranian study ${ }^{8}$. Selectively sending specimens for histopathological examination can result in reduced workload on the histopathology department without compromising patient safety ${ }^{9-12}$.

\section{CONCLUSION}

Routine histopathological examination for all appendicectomy specimens is not necessary but mandatory for peroperative suspicious malignant looking appendix specimens even when equipped laboratory is far, thereby reducing the cost to the patient and overload to the laboratories. It is however recommended that standard criteria to classify malignant and non- Imalignant looking appendices are designed to reduce operator bias.

\section{REFERENCES}

1. Amyand C. Philosophical Transactions of the Royal Society of London 39: 329-336. doi:10.1098/ rstl.1735.0071. 2003.

2. Charfi S, Sellami A, Affes A, Yaich K, Mzali R, Boudawara TS. Histopathological findings in appendectomy specimens: A study of 24,697 cases. Int J Colorectal Dis. 2014 Aug; 29(8): 1009-12.

3. Limaiem F, Arfa N, Marsaoui L, Bouraoui S, Lahmar A, Mzabi S. Unexpected histopathological findings in appendectomy specimens: A retrospective study of 1627 Cases. Indian J Surg. 2015 Dec; 77(Suppl 3): 1285-90.

4. Alemayehu H, Snyder CL, St Peter SD, Ostlie DJ. Incidence and outcomes of unexpected pathology findings after appendectomy. J Pediatr Surg. 2014 Sep; 49(9): 1390-3.

5. Jat MA, Al-Swailmi FK, Mehmood Y, Alrowaili M, Alanazi S. Histopathological examination of appendicectomy specimens at a District hospital of Saudi Arabia. Pak J Med Sci. 2015 Jul-Aug; 31(4): 891-4.

6. Omiyale AO, Adjepong S. Histopathological correlations of appendectomies: A clinical audit of a single center. Ann Transl Med. 2015 Jun; 3(9): 119.

7. Khan RA, Ghani I, Chana RS. Routine histopathological examination of appendectomy specimens in children: is there any rationale? Pediatr Surg Int. 2011 Dec; 27(12): 1313-5.

8. Monajemzadeh M, Hagghi-Ashtiani M-T, MontaserKouhsari L, Ahmadi H, Zargoosh H, Kalantari M. Pathologic evaluation of appendectomy specimens in children: Is routine histopatholgic examination indicated? Iranian Journal of Pediatrics. 2011; 21(4): 485-490.

9. Ramraje SN, Pawar VI. Routine histopathologic examination of two common surgical specimens- 
Original Article | Journal of Gandaki Medical College-Nepal

appendix and gallbladder: Is it a waste of expertise and hospital resources? Indian J Surg. 2014 Apr; 76(2): 127-30.

10. Jones AE, Phillips AW, Jarvis JR, Sargen K. The value of routine histopathological examination of appendicectomy specimens. BMC Surgery. 2007; 7: 17. doi:10.1186/1471-2482-7-17.

11. Sönmez Y, Bayhan Z, Yaylak F, Ekici MF, Değer AN. Appendix adenocarcinoma in an elderly patient from a nursing home. Turkish Journal of Surgery. 2016; 32(2): 149-151.

12. Akbulut S, Tas $\mathrm{M}$, Sogutcu $\mathrm{N}$, et al. Unusual histopathological findings in appendectomy specimens: A retrospective analysis and literature review. World Journal of Gastroenterology. 2011; 17(15): 1961-1970. 